\title{
Detection of Bovine Leukemia Virus in Brains of Cattle with a Neurological Syndrome: Pathological and Molecular Studies
}

\author{
Rubens Henrique Ramos D'Angelino, ${ }^{1}$ Edviges Maristela Pituco, ${ }^{2}$ \\ Eliana Monteforte Cassaro Villalobos, ${ }^{3}$ Ricardo Harakava, ${ }^{4}$ \\ Fábio Gregori, ${ }^{5}$ and Claudia Del Fava ${ }^{6}$ \\ ${ }^{1}$ Pós-Graduação em Sanidade, Segurança Alimentar e Ambiental no Agronegócio, Instituto Biológico de São Paulo (IB), \\ Avenida Conselheiro Rodrigues Alves 1252, Bairro Vila Mariana, 04014-002 São Paulo, SP, Brazil \\ ${ }^{2}$ Laboratório de Viroses de Bovídeos, Centro de P \& D de Sanidade Animal (CPDSA), IB, Avenida Conselheiro Rodrigues Alves 1252, \\ Bairro Vila Mariana, 04014-002 São Paulo, SP, Brazil \\ ${ }^{3}$ Laboratório de Raiva e Encefalites, CPDSA, IB, Avenida Conselheiro Rodrigues Alves 1252, Bairro Vila Mariana, \\ 04014-002 São Paulo, SP, Brazil \\ ${ }^{4}$ Laboratório de Bioquímica Fitopatológica, Centro de Sanidade Vegetal, IB, Avenida Conselheiro Rodrigues Alves 1252, \\ Bairro Vila Mariana, 04014-002 São Paulo, SP, Brazil \\ ${ }^{5}$ Laboratório de Biologia Molecular e Sorologia Aplicadas, Departamento de Medicina Veterinária Preventiva e Saúde Animal, VPS, \\ Faculdade de Medicina Veterinária e Zootecnia da Universidade de São Paulo, Avenida Professor Dr. Orlando Marques de Paiva 87, \\ Cidade Universitária, 05508-270 São Paulo, SP, Brazil \\ ${ }^{6}$ Laboratório de Anatomia Patológica, CPDSA, IB, Avenida Conselheiro Rodrigues Alves 1252, Bairro Vila Mariana, \\ 04014-002 São Paulo, SP, Brazil
}

Correspondence should be addressed to Rubens Henrique Ramos D’Angelino; rhrdangelino@yahoo.com.br and Claudia Del Fava; delfava@biologico.sp.gov.br

Received 26 December 2012; Revised 8 March 2013; Accepted 12 March 2013

Academic Editor: Lubna Nasir

Copyright (C) 2013 Rubens Henrique Ramos D’Angelino et al. This is an open access article distributed under the Creative Commons Attribution License, which permits unrestricted use, distribution, and reproduction in any medium, provided the original work is properly cited.

Bovine leukemia virus (BLV) was investigated in the central nervous system (CNS) of cattle with neurological syndrome. A total of 269 CNS samples were submitted to nested-PCR (BLV env gene gp51), and the viral genotypes were identified. The nestedPCR was positive in 4.8\% (13/269) CNS samples, with 2.7\% (2/74) presenting at histological examination lesions of nonpurulent meningoencephalitis (NPME), whereas 5.6\% (11/195) not presenting NPME $(P>0.05)$. No samples presented lymphosarcoma. The PCR products ( $437 \mathrm{bp}$ ) were sequenced and submitted to phylogenetic analysis by neighbor-joining and maximum composite likelihood methods, and genotypes 1, 5, and 6 were detected, corroborating other South American studies. The genotype 6 barely described in Brazil and Argentina was more frequently detected in this study. The identity matrices showed maximum similarity (100\%) among some samples of this study and one from Argentina (FJ808582), recovered from GenBank. There was no association among the genotypes and NPME lesions.

\section{Introduction}

Bovine encephalitis is an important group of usually fatal diseases that have a strong impact on public health, result in major economic losses worldwide, and present a sanitary barrier to international trade [1]. Agents associated with these diseases include viral, bacterial, parasitic, neoplastic, toxic, and metabolic agents, and all must be considered during differential diagnosis [2].

The importance of differential diagnosis of neurologic syndromes in cattle has increased since 1985, when bovine spongiform encephalopathy (BSE) was first identified in the United Kingdom [3]. Its association with the emergence of a new variant of the human disease Creutzfeldt-Jakob 
Disease (CJD) increased its political, social, and public health significance. International health authorities require evidence from countries exporting meat, which includes Brazil, that their herds are free from BSE and that the causes of encephalitis and encephalopathy are diagnosed and clarified [4]. Decree no. 516 dated December 9, 1997, introduced a BSE surveillance component into the system of surveillance of Herbivore rabies as part of the National Rabies Control of herbivores (PNCRH) of the Ministério da Agricultura, Pecuária e Abastecimento (Ministry of Agriculture, Livestock and Supply, MAPA) [5]. Thus, animals with symptoms of central nerve system disorders must be submitted to a differential diagnosis for rabies and other encephalitides and encephalopathies. These rules are intended to improve specific epidemiological surveillance measures to ensure a country free of BSE [6]. The differential diagnosis and prevention of BSE and the livestock assets in Brazil is of fundamental importance, as is evaluating the risks related to public health and the economic outlook.

Analysis conducted by the Biological Institute from April to July 2002, of samples from 131 cattle with a CNS neurological syndrome [1], confirmed the etiologic agent in only $38.9 \%$ of the samples. Also 21.1\% were positive for rabies (direct immunofluorescence and biological tests), 1.5\% positive for Bovine Viral Diarrhea Virus (BVDV) (isolation, identification by immunoperoxidase and RT-PCR), $0.7 \%$ positive for BoHV-5 (PCR), and $0.7 \%$ were positive for Neospora caninum (conventional PCR). In $16.0 \%$ of the cases, isolation and identification of bacteria (Listeria monocytogenes, Streptococcus spp., Clostridium perfringens, Arcanobacterium pyogenes, Enterobacter cloacae, Pseudomonas aeruginosa, Acinetobacter spp., and Staphylococcus spp.) were obtained. In $61.1 \%$ of the samples, the agent could not be identified using available diagnostic methods (isolation and molecular) making it necessary to investigate other agents and employ other methods.

The Anatomopathology Laboratory of the Biological Institute of São Paulo has been accredited by MAPA resolution number 5 of January 8, 2004 (Federal Official Gazette of Brazil of 09.01.2004, Section 1, page 3), to perform histopathologic differential diagnosis of encephalitis and BSE, thus meeting MAPA's PNCRH criteria. From January 2004 to June 2007, 690 brains of cattle with clinical signs of nervous disorders associated with rabies (direct immunofluorescence) were submitted for histologic examination, with 40\% (276) showing pathological changes and nonpurulent and nonspecific meningoencephalitis being the most frequent lesions observed, at $90.0 \%(249 / 276)$ [7]. This type of inflammatory mononuclear infiltrate indicates microorganisms (viral agents, bacteria, and parasites) causing encephalitis, necessitating sensitive, and specific tests to determine the causative agents.

Bovine leukemia virus (BLV), which causes bovine leukosis (BL), is widespread in all regions of Brazil with high incidence of seroreactivity in dairy herds and other livestock under intensive management [8], although lymphosarcoma in the CNS has been reported as a rare condition in cattle $[9,10]$.
Del Fava et al. [10] reported the occurrence of $0.03 \%$ (1/2867) intracerebral lymphosarcoma in bovine with neurological syndrome, in a surveillance period of seven years, in Brazil. The tumoral mass was positive to nested-PCR (BLV env gene gp51). The RFLPA analyses using enzyme Bam HI revealed a site in amplified segments of BLV env gene, providing information about its population polymorphism, and allowed to classify into the Japanese-North American subgroup. The amplified proviral DNA was analyzed using ABI Prism 377 DNA sequencer (Applied Biosystems), and the obtained sequence was aligned and compared with others present in GenBank, by program BLAST, confirming the subgroup.

Given that BLV induces seroconversion, causes persistent lymphocytosis, and may rarely lead to lymphosarcoma, and that there are many cases with non-purulent meningoencephalitis (NPME) in which a causative diagnosis cannot be made, the aim of this study was to investigate BLV as a possible cause of neurological syndrome in cattle testing negative for rabies.

\section{Materials and Methods}

Bovine leukemia virus infection was verified from CNS samples of 269 cattle with neurological symptoms referred to the Centro de Pesquisa e Desenvolvimento de Sanidade Animal of Instituto Biológico (Center of Research and Development of Animal Health of the Biological Institute) from January 2007 to December 2009, for differential diagnosis of neurological syndrome. The samples were collected by government and private veterinarians, and all samples were negative for rabies virus based on the antirabies conjugate labeled with fluorescein isothiocyanate (Sanofi) and in vivo testing [11].

Tissues were fixed in $10 \%$ buffered formalin, cut into smaller pieces, and then dehydrated, cleared, and embedded in paraffin; sections were cut at $5 \mu \mathrm{m}$ and stained with hematoxylin and eosin [12].

DNA extraction was made from chilled tissue samples using the Wizard Genomic DNA Purification kit (Promega Corporation, Madison, WI, USA-Cat. no. A1120). Amplification of the segment that encodes the gp51 env gene of the BVL was conducted by nested PCR, using specific primers for amplifying a segment of 440 base pairs (bp) [13]. Briefly, the PCR reaction conditions were as follows: volume of DNA in the first and second amplification was $5 \mu \mathrm{L}$ and $1.5 \mu \mathrm{L}$, respectively; concentration of external and internal primers, 0.2 and $0.1 \mu \mathrm{M}$; initial denaturation at $94^{\circ} \mathrm{C}$ for $2 \mathrm{~min}$; 40 repeat cycles of denaturation at $95^{\circ} \mathrm{C}$ for $30 \mathrm{sec}$; annealing at $62^{\circ} \mathrm{C}$ for $30 \mathrm{sec}$ in the first and $70^{\circ} \mathrm{C}$ for $30 \mathrm{sec}$ in the second amplification; extension at $72^{\circ} \mathrm{C}$ for $1 \mathrm{~min}$; final extension at $72^{\circ} \mathrm{C}$ for $4 \mathrm{~min}$. Analysis of amplified products was by electrophoresis ( $100 \mathrm{~V} / 60 \mathrm{~min})$ agarose gel at $1.5 \%$ in Tris plug, sodium acetate, EDTA $\mathrm{pH}$ 8.0, and stained with ethidium bromide. The image of the gel under UV light was recorded using camera coupled to a computer.

The positive PCR products were purified with the Wizard Genomic DNA Purification kit (Promega Corporation, Madison, WI, USA-Cat. no. A7170) and subjected to 
sequencing reaction by chain termination with dideoxynucleotides marked with fluorophores. The reaction was performed with $5.68 \mu \mathrm{L}$ of the PCR product, $2 \mu \mathrm{L}$ reagent Big Dye 3.1 (Applied Biosystems), $2 \mu \mathrm{L}$ of dilution buffer $(0.2 \mathrm{M}$ Tris- $\mathrm{HCl} \mathrm{pH} 9.0,5 \mu \mathrm{L} \mathrm{MgCl}_{2}$ ), and $0.32 \mu \mathrm{L}$ of a primer used in PCR (final concentration $0.32 \mu \mathrm{L}$ ) to a total volume of $10 \mu \mathrm{L}$. Each sample was sequenced in both directions using forward and reverse primers. The samples were incubated in a thermocycler (PTC-100, MJ Research) for 25 cycles at $95^{\circ} \mathrm{C}$ for $10 \mathrm{sec}$ and $60^{\circ} \mathrm{C}$ for $4 \mathrm{~min}$. The sequencing reaction products were precipitated by adding $40 \mu \mathrm{L}$ of $75 \%$ isopropanol and centrifugation R-5810 centrifuge (Eppendorf) at $3220 \times \mathrm{g}$ for $30 \mathrm{~min}$ at room temperature. After discarding the supernatant, another $100 \mu \mathrm{L}$ of $75 \%$ isopropanol was added for washing the precipitate, and the supernatant was again discarded, without centrifugation. The precipitate was dried by incubation at $37^{\circ} \mathrm{C}$ for $30-60 \mathrm{~min}$. The precipitate was re-suspended in $2 \mu \mathrm{L}$ of formamide, denatured at $95^{\circ} \mathrm{C}$ for $2 \mathrm{~min}$, and subjected to electrophoresis in denaturing polyacrylamide gel in ABl377 automated sequencer (Applied Biosystems).

The generated sequences were analyzed by the program Bioedit v.7.0.9 [14] to generate a unique sequence from the bidirectional sequence data. They were then aligned to each other and to homologues retrieved from Genbank, using the Clustal W version 1.8.3 software [14].

After definition of a consensus block, a table of nucleotide and amino acid identity was constructed using the software Bioedit v.7.0.9 [14]. Phylogenetic inference was performed using the program Mega, version 5 [15]. The tree generated from the nucleotide sequence was constructed with the neighbor-joining method using the substitution pattern maximum composite likelihood for the partial region (437 nt) of the env glycoprotein 51 gene from the BLV (nt 5110-5546 having as reference a sample of BLV, Argentina Accession no. AF257515), representing approximately $50 \%$ of the total gene, with the bootstrap values defined from 1000 replicates, with values equal to or greater than 50 submitted to the next node.

The association between the histopathologic findings of non-purulent, nonspecific meningoencephalitis and results of nested PCR, positive or not, was evaluated using Fisher's two-tailed exact test with an alpha error 5\% [16].

\section{Results and Discussion}

The 269 CNS tissue samples from cattle with a CNS neurological syndrome showed a high number with characteristic lesions of NPME, corroborating with Del Fava et al. [7], but the nested-PCR showed low positivity for BLV (Table 1). These data indicated that other infectious agents, including rabies, are important in the differential diagnosis of diseases of the CNS in cattle, as was demonstrated in southern Brazil [4].

Statistical analysis by Fisher's exact test [16] showed no significant ( $\alpha=5 \%, P=0.52, \mathrm{CI}=0.1073$ to 2.083 ) positive correlation between nested-PCR results and the presence of lesions characteristic of NPME.
TABLE 1: Correlation between histopathology of CNS of cattle with neurological syndrome and results of nested-PCR.

\begin{tabular}{lccc}
\hline \multirow{2}{*}{ Histology (\%) } & \multicolumn{2}{c}{ Nested-PCR (\%) } & \multirow{2}{*}{ Total (\%) } \\
& Positive & Negative & \\
\hline NPME & $2(0.7)^{\mathrm{a}}$ & $72(26.8)^{\mathrm{a}}$ & $74(27.5)$ \\
Without alterations & $11(5.6)^{\mathrm{a}}$ & $184(68.4)^{\mathrm{a}}$ & $195(72.5)$ \\
Total (\%) & $13(4.8)$ & $256(95.2)$ & $269(100)$ \\
\hline
\end{tabular}

Same superscript letters between columns are not significantly different at 0.05 .

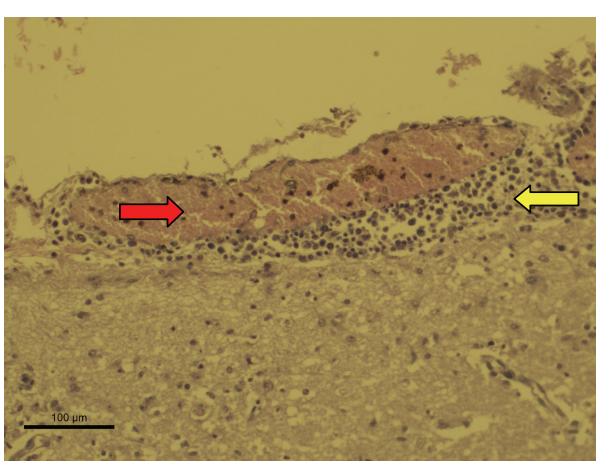

Figure 1: Nonpurulent meningitis (H \& E 200x magnification). Bovine brain, positive for BLV, with accumulation of mononuclear inflammatory cells along the meninges (yellow arrows) and apparent congestion (red arrow).

Taking into account the high seroprevalence of BLV in recent decades in Brazil [17-19], especially in dairy herds, it is suspected that the low detection of genetic material (proviral DNA) of BLV by nested-PCR (13/269, 4.8\%) may be due to low or absent neurotropism and/or in the difficulty of the virus in crossing the blood-brain barrier, even in animals with inflammatory changes of the CNS. The number of cases found positive with nested-PCR in samples with NPME $(15.4 \%-2 / 13)$ was low in the present study. Another possible reason for this discrepancy is the connection of BLV with lymphoid tissue, particularly B lymphocytes [20, 21], and not the CNS itself. For this reason, a higher incidence of neoplastic changes is found in lymph nodes than in spleen, heart, uterus, abomasum, liver, and kidneys [22].

Positivity to BLV in animals with NPME may be due to the presence of the integrated virus in the lymphocyte genome, which is infiltrated in the tissues. On the other hand, in the positive nested-PCR animals that did not reveal NPME $(84.6 \%-11 / 13)$, it can be assumed that the presence of proviral DNA in some samples may have been due to amplification of the genetic material from the intraluminal lymphocytes of cerebral blood vessels, taking into account that around 30\%$70 \%$ of infected animals have shown persistent lymphocytosis [23].

In samples showing characteristics consistent with NPME, regardless of BLV status, meningeal inflammatory infiltration (Figure 1) and accumulation of inflammatory cells along the Virchow-Robin space were evident (perivascular cuffing) (Figure 2). 
TABLE 2: Sequences with maximum and minimum similarity of nucleotides and of amino acids in the consensus region, when compared with one another and with GenBank sequences.

\begin{tabular}{|c|c|c|}
\hline Similarity & Nucleotide Identity & Amino acid identity \\
\hline \multirow[t]{2}{*}{$\begin{array}{l}\text { Among the sequences of } \\
\text { this study }\end{array}$} & $\begin{array}{l}\text { Maximum }(100 \%) \\
\text { (i) JN254633, JN254635, JN254637 and JN254638 } \\
\text { (ii) JN254636 and JN254640 }\end{array}$ & $\begin{array}{l}\text { Maximum }(100 \%) \\
\text { (i) JN254633, JN254635, JN254637 and JN254638 } \\
\text { (ii) JN254636 and JN254640 }\end{array}$ \\
\hline & $\begin{array}{l}\text { Minimum }(95.8 \%) \\
(\text { i) JN254634 × JN254633, JN254635, JN254637 and } \\
\text { JN254638 }\end{array}$ & $\begin{array}{l}\text { Minimum }(96.5 \%) \\
(\text { i) JN254634 × JN254633, JN254635, JN254637 and } \\
\text { JN254638 }\end{array}$ \\
\hline \multirow[t]{2}{*}{$\begin{array}{l}\text { Among the sequences of } \\
\text { the study before the other } \\
\text { retrieved from GenBank }\end{array}$} & $\begin{array}{l}\text { Maximum }(100 \%) \\
\text { (i) JN254633, JN254635, JN254637, JN254638 } \\
\text { and FJ808582 } \\
\text { (ii) JN254636, JN254640 and EF065640 }\end{array}$ & $\begin{array}{l}\text { Maximum (100\%) } \\
\text { (i) JN254633, JN254635, JN254637, JN254638 and } \\
\text { FJ808582 } \\
\text { (ii) JN254636, JN254640 and EF065640 } \\
\text { (iii) JN254639 and AY185360 }\end{array}$ \\
\hline & $\begin{array}{l}\text { Minimum }(94 \%) \\
\text { (i) JN254634 × EU266062 }\end{array}$ & $\begin{array}{l}\text { Minimum }(92.4 \%) \\
\text { (i) EU266062 × JN254634, JN254634, JN254635, } \\
\text { JN254638 and JN254638 }\end{array}$ \\
\hline
\end{tabular}

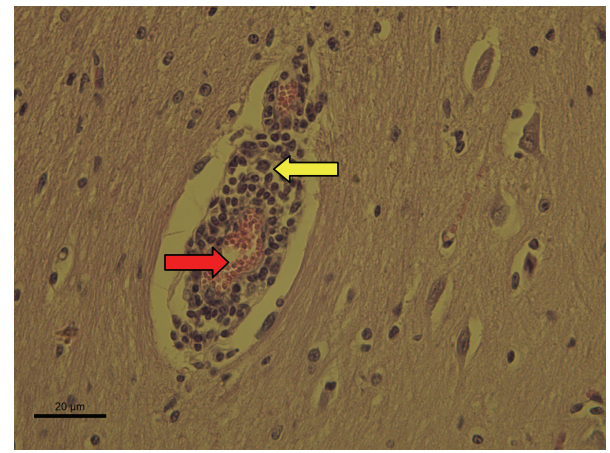

FIgURE 2: Non-purulent encephalitis (H \& E 400x magnification). Bovine brain, positive for BLV, with mononuclear cell infiltrates in the Virchow-Robin space (yellow arrows) characterizing the perivascular cuffing. The red arrows indicate the vascular lumen, with red blood cells within.

Comparison of the nucleotide and amino acid identity matrix (Table 2) of the sequenced samples from this work showed $100 \%$ identity among the BLV samples JN254633, JN254637, and JN254638, all from São Paulo, and with BLV sample JN254635 from Mato Grosso State. When compared to GenBank sequences, these samples showed $100 \%$ identity with sequence FJ808582, originally from Argentina [24]. Maximum identity was also found between samples BLV 04 (JN254636) from São Paulo State and 13 (JN254640) from Mato Grosso, which were identical to the retrieved sequences from GenBank EF065640, originally described in Costa Rica [25].

A high mutation rate of retroviruses has been reported, linking this to reverse transcriptase due to the high number of replication cycles [26]. The rates of nucleotide mutation of BLV are $0.009 \%$ and $0.034 \%$ in regions corresponding to the env gene and long terminal repeat (LTR), respectively [27]. However, it was evident in the present work, based on minimal similarities of identity matrices, that both nucleotide
(94\%) and amino acid (92.4\%) present a clear conservation of nucleotide sequences, confirming findings of Portetelle et al. [28] and Felmer et al. [29] that the BLV can conserve its genetic characteristics in different geographical areas for long periods.

Phylogenetic analysis of eight partial sequences of the env gene (gp51) of BLV showed the presence of three genotypes, they were represented in the phylogenetic tree (Figure 3), and they corresponded to the identity matrix and to the genotypes previously described [24, 30, 31]. Its topology confirmed the separate genotypes reported by these cited authors. Discussions and controversies have been generated concerning the number of genotypes of BLV but have evolved to consensus on the existence of at least seven genotypes, based both on studies using PCR-RFLP and those employing sequencing analyzes [24, 30, 32]. However, evidence for an eighth genotype was reported by Hemmatzadeh [33] and suggested by Matsumura et al. [31], which is why it was considered by this study.

Based on the phylogenetic analysis of the partial region of the env gene, none of the identified genotypes was associated with NPME in cattle with neurological syndrome. There is no currently available information on the pathogenicity of BLV genotypes to different organs, including the bovine CNS. Although the development of a tumoral form of bovine leukosis has been described as dependent on host susceptibility $[34,35]$, there is currently no evidence for whether some genotypes can influence or induce these neoplasias.

\section{Conclusions}

The results indicate that BLV has no tropism in the CNS, and it cannot be regarded as the primary causative agent of non-purulent meningoencephalitis in cattle. The observed genotypes corroborate previous studies conducted in Brazil. Bovine leukemia virus cannot be excluded from the differential diagnosis of neurological syndrome because, despite 


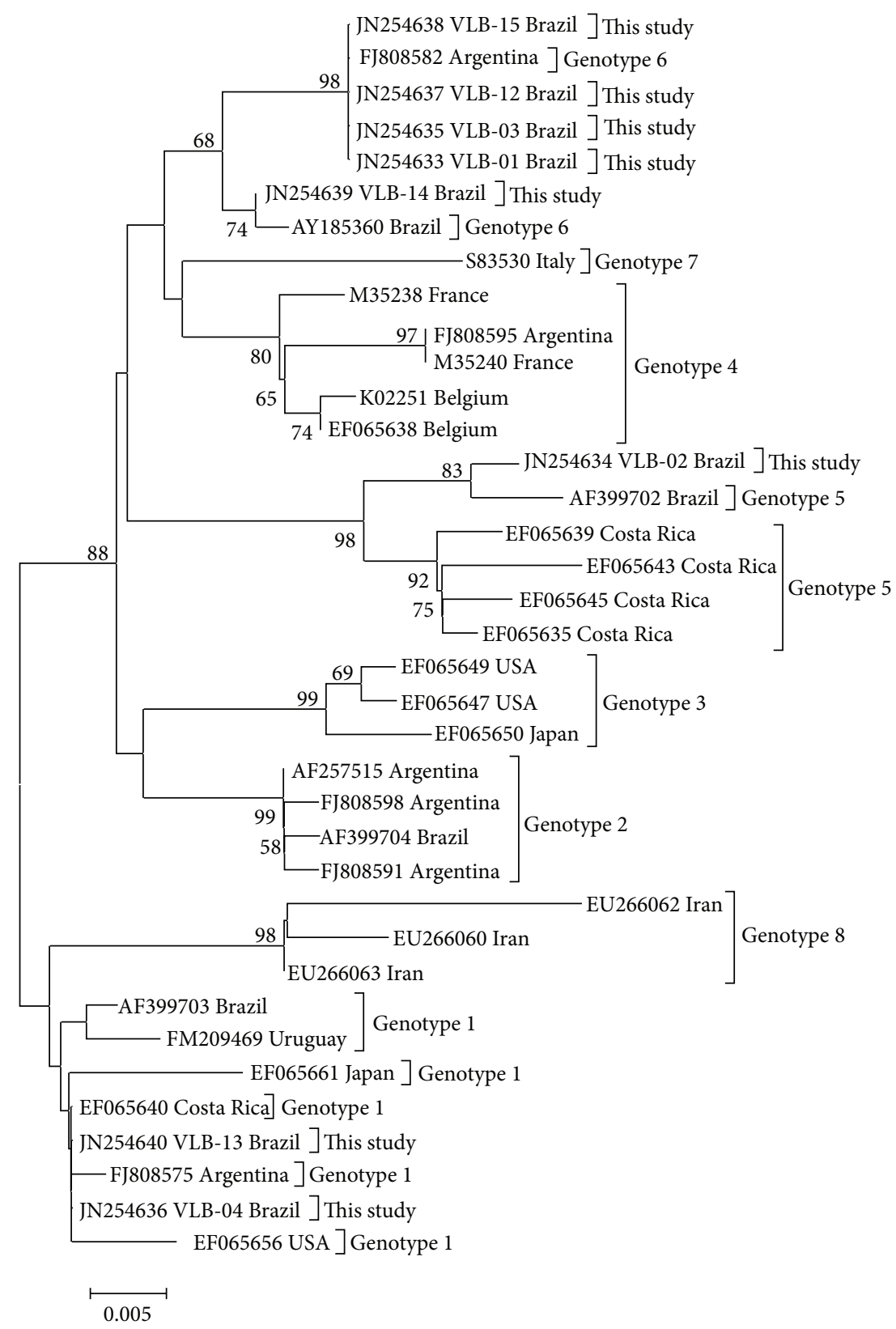

Figure 3: Phylogenetic tree developed by the neighbor-joining method with the substitution pattern maximum composite likelihood (Software Mega v. 5). The samples show identification Accession Number/country of study/genotype referring to the env gene. The numbers near each node represent the values of 1000 bootstrap replicates, showing only those greater than $50 \%$. The scale represents the number of replacements/sites.

being rare, the presence of lymphosarcomas in the CNS has been reported in Brazil.

\section{Acknowledgment}

The authors would like to thank FAPESP (Research Support Foundation of São Paulo, SP, Brazil) for Masters Scholarship Process no. 2010/04692-6 and for Research Grant Process no. 2011/06513-4. They also want to thank the Scientific Researcher Alice Akimi Ikuno for her assistance.

\section{References}

[1] E. M. Pituco, E. M. S. Cunha, M. C. C. S. H. Lara et al., "Encefalites e encefalopatias dos bovinos: sistematização do diagnóstico diferencial," in Proceedings of the 11th Latinoamerican Buiatrics Congress and the 5th Brazilian Buiatrics Congress, p. 46, Brazilian Buiatrics Association, Salvador, Brazil, 2003.

[2] C. S. L. Barros, D. Driemeier, I. S. Dutra, and R. A. A. Lemos, Doenças do Sistema Nervoso de Bovinos no Brasil, Vallée, Montes Claros, Brazil, 2006.

[3] G. A. Wells, A. C. Scott, C. T. Johnson et al., "A novel progressive spongiform encephalopathy in cattle," Veterinary Record, vol. 121, no. 18, pp. 419-420, 1987. 
[4] A. W. D. Sanches, I. M. Langohr, A. L. Stigger, and C. S. L. Barros, "Doenças do sistema nervoso central em bovinos no Sul do Brasil," Pesquisa Veterinária Brasileira, vol. 20, pp. 113-118, 2000.

[5] Ministério da Agricultura, Pecuária e AbastecimentoMAPA, Programa Nacional de Controle da Raiva e outras Encefalopatias-PNCRH, Brasília, Brazil, 2011, http://www.agricultura.gov.br/.

[6] C. S. L. Barros and G. H. F. Marques, Procedimentos para o Diagnóstico de Doenças do Sistema Nervoso Central de Bovinos, MAPA/SDA/DDA, Brasília, Brazil, 2003.

[7] C. Del Fava, R. Macruz, M. C. C. S. H. Lara et al., "Diagnóstico de encefalites e encefalopatias espongiformes transmissíveis em ruminantes no período de 2004 a 2007 no Estado de São Paulo, Brasil," Archives of Veterinary Science, vol. 12, pp. 83-84, 2007.

[8] C. Del Fava and E. M. Pituco, "Aspectos da infecção pelo vírus da leucose enzoótica bovina em bovinos no Brasil," Biológico, vol. 66, pp. 1-8, 2004.

[9] R. A. Fighera and C. S. L. Barros, "Intracerebral lymphosarcoma in a cow," Ciência Rural, vol. 34, pp. 943-945, 2004.

[10] C. Del Fava, A. A. Ikuno, R. Harakava, M. C. C. S. H. Lara, and E. M. Pituco, "Molecular study of bovine leukemia virus causing lymphosarcoma in bovine central nervous system," Virus Reviews and Research, vol. 16, no. 1, p. 232, 2011.

[11] D. J. Dean, M. K. Abelseth, and P. Atanasiu, "Routine laboratory procedures: the fluorescent antibody test," in Laboratory Techniques in Rabies, F. X. Meslin, M. M. Kaplan, and H. Koprowski, Eds., pp. 88-95, World Health Organization, Genebra, Switzerland, 4th edition, 1996.

[12] E. B. Prophet, B. Mills, J. B. Arrington, and L. H. Sobin, Eds., Métodos Histotecnológicos, Registro de Patologia de los Estados Unidos de América y Instituto de Patología de las Fuerzas Armadas de los Estados Unidos de América, Washington, DC, USA, 1992.

[13] D. Beier, P. Blankenstein, O. Marquardt, and J. Kuzmak, "Identification of different BLV provirus isolates by PCR, RFLPA and DNA sequencing," Berliner und Munchener Tierarztliche Wochenschrift, vol. 114, no. 7-8, pp. 252-256, 2001.

[14] T. A. Hall, "Bioedit: a user-friendly biological sequence alignment editor and analysis program for Windows 95/98/NT," Nucleic Acids Symposium Series, vol. 41, pp. 95-98, 1999.

[15] K. Tamura, J. Dudley, M. Nei, and S. Kumar, "MEGA4: Molecular Evolutionary Genetics Analysis (MEGA) software version 4.0," Molecular Biology and Evolution, vol. 24, no. 8, pp. 15961599, 2007.

[16] E. S. Berquó, J. M. P. Souza, and S. L. D. Gotlieb, Bioestatística, Editora Pedagógica e Universitária Ltda., São Paulo, Brazil, 1981.

[17] R. C. Leite, C. M. Modena, E. C. Moreira, and J. J. Abreu, "Evolução clínica da leucose enzoótica bovina," Arquivo Brasileiro de Medicina Veterinária e Zootecnia, vol. 36, pp. 47-57, 1984.

[18] E. H. Birgel Júnior, J. L. D’Angelino, F. J. Benesi, and E. H. Birgel, "Prevalência da infecção pelo vírus da Leucose dos bovinos, em animais da raça Jersey, criados no estado de São Paulo," Pesquisa Veterinária Brasileira, vol. 15, pp. 93-99, 1995.

[19] J. Megid, C. N. Nozaki, R. B. S. Kuroda, T. F. Cruz, and K. C. Lima, "Ocorrência de leucose enzoótica bovina na microrregião da Serra de Botucatu," Arquivo Brasileiro de Medicina Veterinária e Zootecnia, vol. 55, pp. 645-646, 2003.
[20] Y. Aida, M. Miyasaka, K. Okada et al., "Further phenotypic characterization of target cells for bovine leukemia virus experimental infection in sheep," American Journal of Veterinary Research, vol. 50, no. 11, pp. 1946-1951, 1989.

[21] I. Schwartz, A. Bensaid, B. Polack, B. Perrin, M. Berthelemy, and D. Levy, "In vivo leukocyte tropism of bovine leukemia virus in sheep and cattle," Journal of Virology, vol. 68, no. 7, pp. 45894596, 1994.

[22] A. L. Parodi, "Pathology of enzootic bovine leukosis: comparision with the sporadic form," in Enzootic Bovine Leukosis and Bovine Leukemia Virus, A. Burny and M. Mammerickx, Eds., pp. 15-49, Martinus Nijhoff, Boston, Mass, USA, 1987.

[23] J. F. Ferrer, "Bovine leukosis: natural transmission and principles of control," Journal of the American Veterinary Medical Association, vol. 175, no. 12, pp. 1281-1286, 1979.

[24] S. M. Rodriguez, M. D. Golemba, R. H. Campos, K. Trono, and L. R. Jones, "Bovine leukemia virus can be classified into seven genotypes: evidence for the existence of two novel clades," Journal of General Virology, vol. 90, no. 11, pp. 2788-2797, 2009.

[25] X. Zhao and G. C. Buehring, "Natural genetic variations in bovine leukemia virus envelope gene: possible effects of selection and escape," Virology, vol. 366, no. 1, pp. 150-165, 2007.

[26] L. M. Mansky and H. M. Temin, "Lower mutation rate of bovine leukemia virus relative to that of spleen necrosis virus," Journal of Virology, vol. 68, no. 1, pp. 494-499, 1994.

[27] L. Willems, R. Kettmann, F. Dequiedt et al., "In vivo infection of sheep by bovine leukemia virus mutants," Journal of Virology, vol. 67, no. 7, pp. 4078-4085, 1993.

[28] D. Portetelle, D. Couez, C. Bruck et al., "Antigenic variants of bovine leukemia virus (BLV) are defined by amino acid substitutions in the $\mathrm{NH} 2$ part of the envelope glycoprotein gp51," Virology, vol. 169, no. 1, pp. 27-33, 1989.

[29] R. Felmer, G. Muñoz, J. Zúñiga, and M. Recabal, "Molecular analysis of a $444 \mathrm{bp}$ fragment of the bovine leukaemia virus gp51 env gene reveals a high frequency of non-silent point mutations and suggests the presence of two subgroups of BLV in Chile," Veterinary Microbiology, vol. 108, no. 1-2, pp. 39-47, 2005.

[30] G. Moratorio, G. Obal, A. Dubra et al., "Phylogenetic analysis of bovine leukemia viruses isolated in South America reveals diversification in seven distinct genotypes," Archives of Virology, vol. 155, no. 4, pp. 481-489, 2010.

[31] K. Matsumura, E. Inoue, Y. Osawa, and K. Okazaki, "Molecular epidemiology of bovine leukemia virus associated with enzootic bovine leukosis in Japan," Virus Research, vol. 155, no. 1, pp. 343348, 2011.

[32] E. Inoue, K. Matsumura, K. Maekawa et al., "Genetic heterogeneity among bovine leukemia viruses in Japan and their relationship to leukemogenicity," Archives of Virology, vol. 156, no. 7, pp. 1137-1141, 2011.

[33] F. Hemmatzadeh, "Sequencing and phylogenetic analysis of gp51 gene of bovine leukaemia virus in iranian isolates," Veterinary Research Communications, vol. 31, no. 6, pp. 783-789, 2007.

[34] H. A. Lewin and D. Bernoco, "Evidence for BoLA-linked resistance and susceptibility to subclinical progression of bovine leukaemia virus infection," Animal Genetics, vol. 17, no. 3, pp. 197-207, 1986.

[35] O. M. Radostitis, C. C. Gay, D. C. Blood, and K. W. Hinchcliff, Eds., Clínica Veterinária-Um Tratado de Doenças dos Bovinos, Ovinos, Suínos, Caprinos e Equinos, Guanabara Koogan, Rio de Janeiro, Brazil, 9th edition, 2002. 


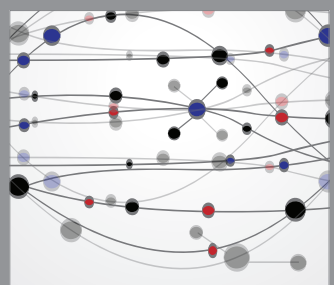

The Scientific World Journal
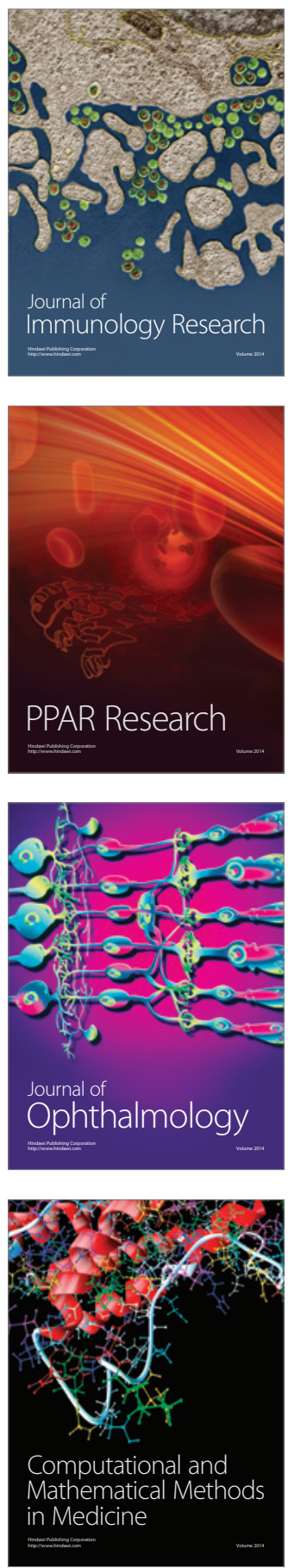

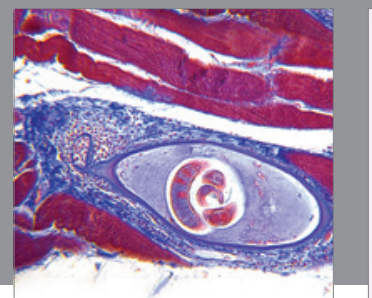

Gastroenterology

Research and Practice
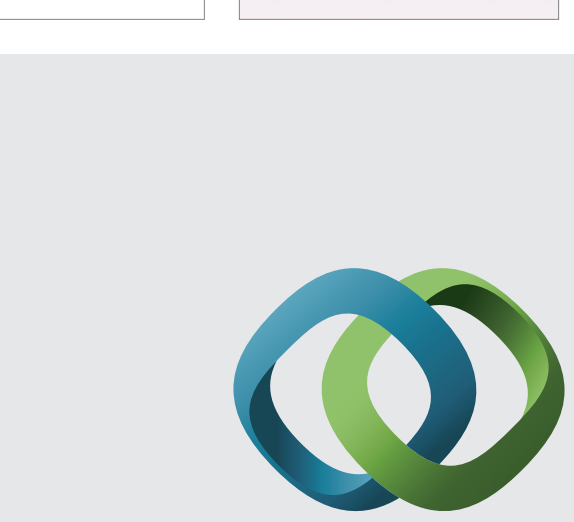

\section{Hindawi}

Submit your manuscripts at

http://www.hindawi.com
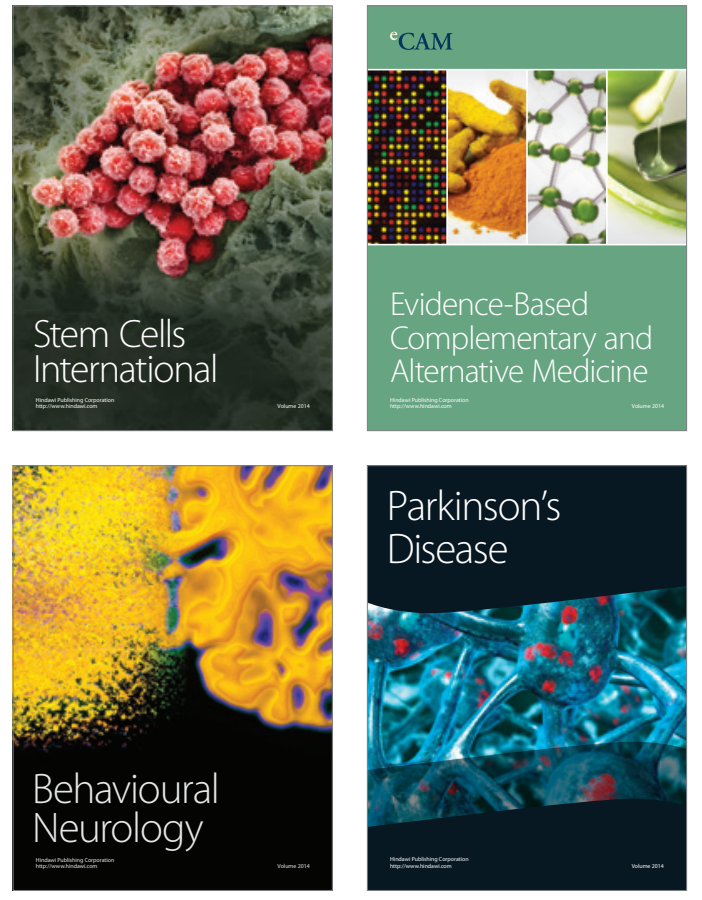
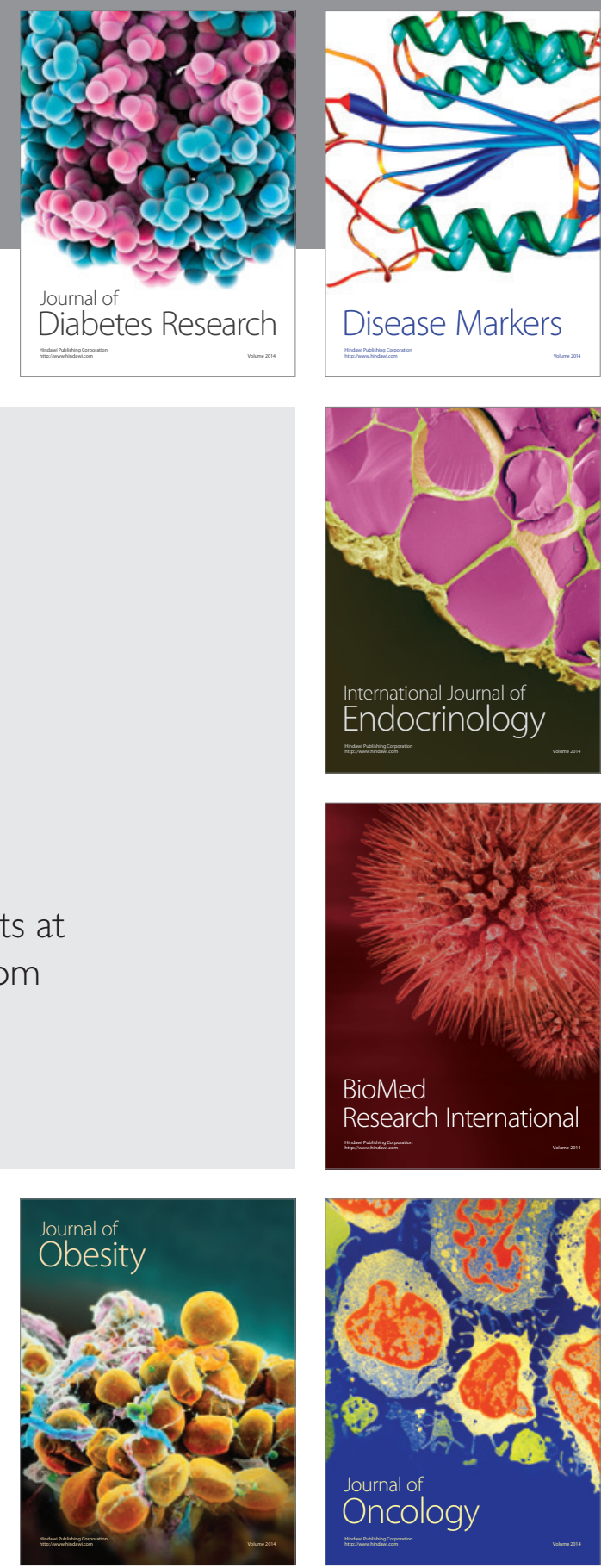

Disease Markers
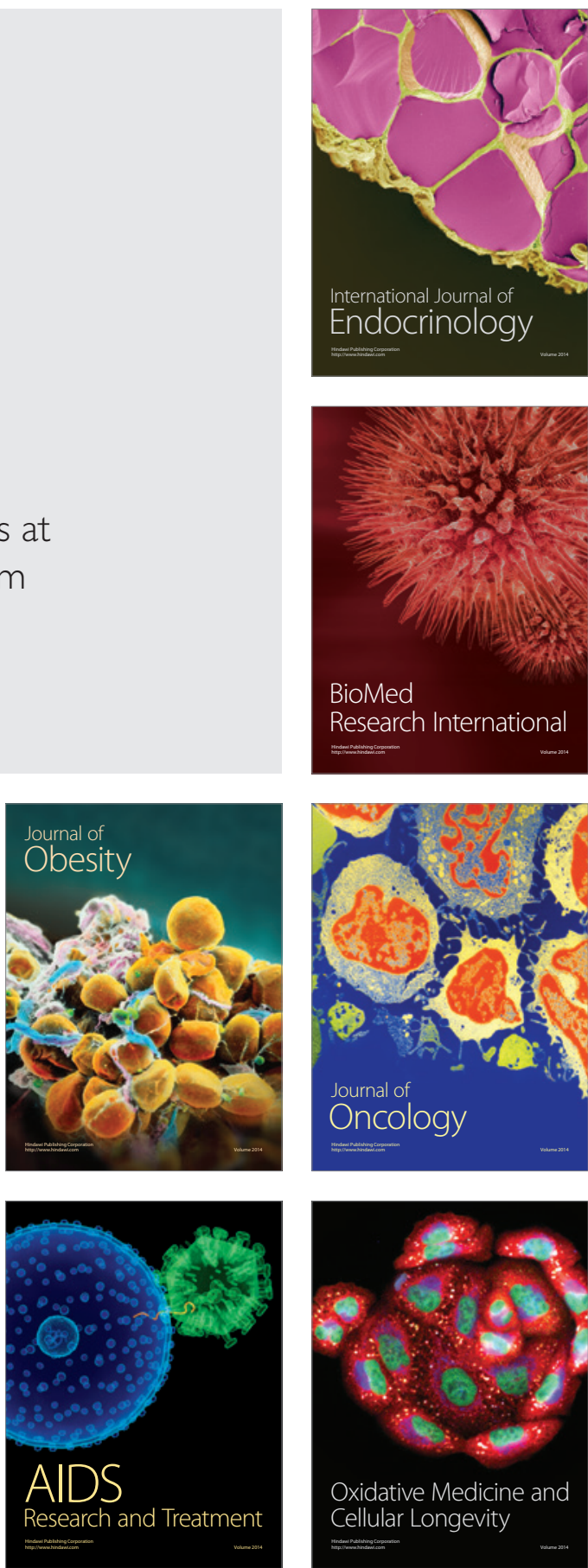